\title{
パクリタキセル・カルボプラチンによる術前補助化学療法が奏功した 扁平上皮への分化を伴う膀胱尿路上皮癌の一例
}

\author{
${ }^{1)}$ 耳原総合病院泌尿器科, ${ }^{2)}$ 耳原総合病院病理科, ${ }^{3)}$ 菅野クリニック \\ 坂野 恵里 ${ }^{11}$ 西野 安紀 ${ }^{11}$ 永井 康晴 ${ }^{11}$ 安田 宗生 ${ }^{11}$ \\ 田原 秀男 ${ }^{1)}$ 木野 茂生 ${ }^{2)}$ 菅野 展史 ${ }^{3)}$
}

\begin{abstract}
要旨:
症例は 42 歳, 男性. 無症候性肉眼的血尿にて近医受診，膀脱鏡にて膀胱右側壁に粘膜発赤あり，膀胱生検 目的に当院へ紹介. CT, MRI にて右水腎症と膀胱に近接した右骨盤内に境界不明瞭な $40 \mathrm{~mm}$ 大の腫瘍を認め た. 2012 年 2 月, 経尿道的膀胱腫瘍切除術を施行, 病理組織の結果は扁平上皮癌であった. PET-CTでも当該 腫瘍以外に集積を認めず，後腹膜原発扁平上皮癌として肺扁平上皮癌に準じたパクリタキセル・カルボプラ チンによる化学療法（weekly TC 療法）を 1 コース施行, 腫瘍は $29 \mathrm{~mm}$ に縮小. 同年 4 月, 右腎尿管全摘, 膀胱尿道全摘除抢よび回腸導管造設術を施行. 病理組織の結果は TUR 部にごくわずかに上皮内癌 (以下 CIS) を認めていたため, 扁平上皮への分化を伴う尿路上皮癌と診断した．術後補助化学療法として weekly TC 療法を 2 コース施行. 術後 11 カ月の腹部 CT で肝転移抢よび骨盤内に局所再発を認めたため, weekly TC 療法を 2 コース施行するも骨盤内の局所再発が増大. GC 療法に切り替えたが腎障害のため 1 コースで中止. 術後 17 カ月で局所再発の腸管浸潤による消化管出血により癌死した。
\end{abstract}

（日泌尿会誌 $106(3) ： 206 ２ 10,2015)$

キーワード: パクリタキセル, 膀胱扁平上皮癌, 術前補助化学療法

\section{緒言}

今回, 我々は後腹膜腫瘍との鑑別に難渋し, 当初は後 腹膜原発扁平上皮癌と診断した膀胱癌に対し, 術前補助 化学療法として paclitaxel, carboplatin を使用した症例 を経験したので報告する。

\section{症例}

患者 : 41 歳, 男性.

主訴：無症候性肉眼的血尿.

既往歴 : 40 歳 急性喉頭蓋炎.

現病歴：2011 年 12 月無症候性肉眼的血尿にて近医泌 尿器科を受診. 尿細胞診, 経静脈的腎孟造影で異常を認 めず，膀胱鏡では右側壁に浮腫状粘膜認めるも悪性を疑 う所見ではなく, 経過観察となっていた. 2012 年 1 月に 再度肉眼的血尿を認め, 膀胱生検目的にて当科紹介と なった。

初診時現症：身長 $178 \mathrm{~cm}$, 体重 $67.2 \mathrm{~kg}$, 右下腹部に軽 度の圧痛を認めた。

初診時検査所見：血液生化学検査, 尿検査ともに特記 すべき所見はなく，尿細胞診にて異型扁平上皮細胞を認
めた．腫瘍マーカーは SCC 1.0ng/ml（基準值 $<1.5 \mathrm{ng} /$ $\mathrm{ml}$ ), その他 CEA, CA19-9, NSE などは基準範囲内.

画像所見：CTでは右側の膀胱尿管移行部付近に40 $\mathrm{mm}$ 大の腫瘤および右水腎症を認めた (Fig. 1A, B). MRI では膀胱右側に境界不明瞭な腫瘤を認め, 右内閉鎖筋へ の浸潤が疑われた (Fig. 1C).

治療経過：2012 年 2 月に経尿道的膀胱腫瘍切除術 （TUR-BT）を施行. 膀胱右側壁に正常粘膜に覆われた隆 起性病変があり, 中心部から出血を認めた.この部分を 生検目的に一部切除したところ, 病理組織の結果は squamous cell carcinoma であった. 当初は膀胱外発生と 考え, 原発巣検索のため上部・下部消化管内視鏡検査お よび胸部 CT 検査を施行したが異常を認めなかった．腫 瘍マーカーに特異的な上昇は認めず, PET-CT では骨盤 内腫瘤以外に異常集積は認めなかった. 以上より, 後腹 膜原発の扁平上皮癌と診断した。呼吸器外科コンサルト のもと，パクリタキセルおよびカルボプラチンを用いた 肺扁平上皮癌に準じた化学療法 (以下weekly TC 療 法)を行い, 腫瘍が縮小していれば手術を行う方針となっ た. 2012 年 3 月, weekly TC 療法 (paclitaxel 60mg/ $\mathrm{m}^{2}$, carboplatin AUC2 on Day1, 8,15）を開始. 1 コース終了

受付日：2014 年 9 月 19 日, 受理日：2014 年 12 月 3 日

坂野恵里：耳原総合病院泌尿器科〔 $\overline{7} 590-8505$ 大阪府堺市協和町 4 丁 465〕

E-mail: eribanno@med.kindai.ac.jp

(C) 2015 The Japanese Urological Association 
Fig. 1 治療前画像所見

$\mathrm{A}, \mathrm{B}$ ：腹部 C T 膀胱右側の腫瘤（矢印）により右水腎症を来していた

C : 骨盤 MRI 境界不明瞭な腫瘤を認め, 内閉鎖筋への浸潤が疑われた
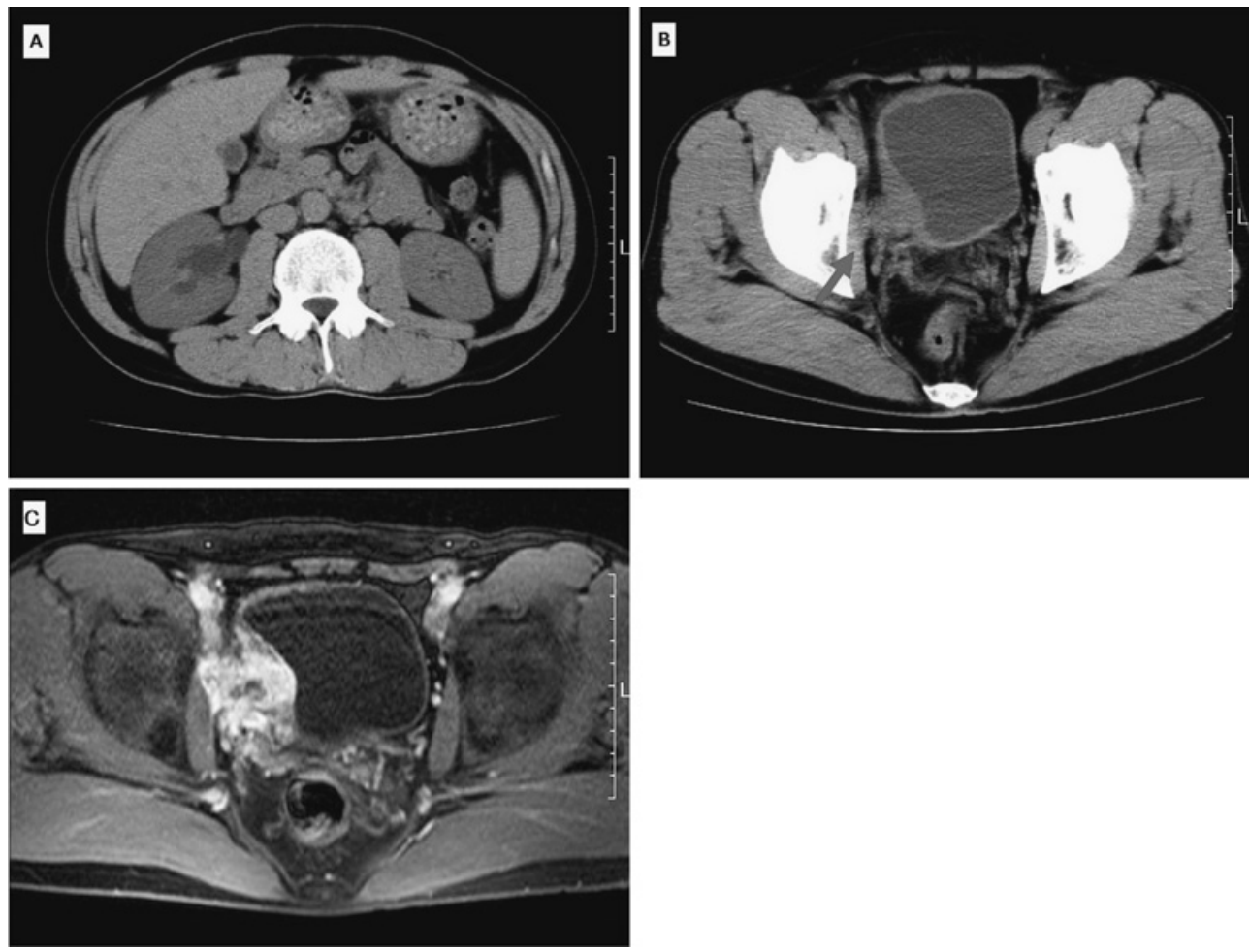

Fig. 2 化学療法 1 コース終了後骨盤 MRI 腫瘍は $40 \mathrm{~mm}$ から $29 \mathrm{~mm}$ 大に縮小していた

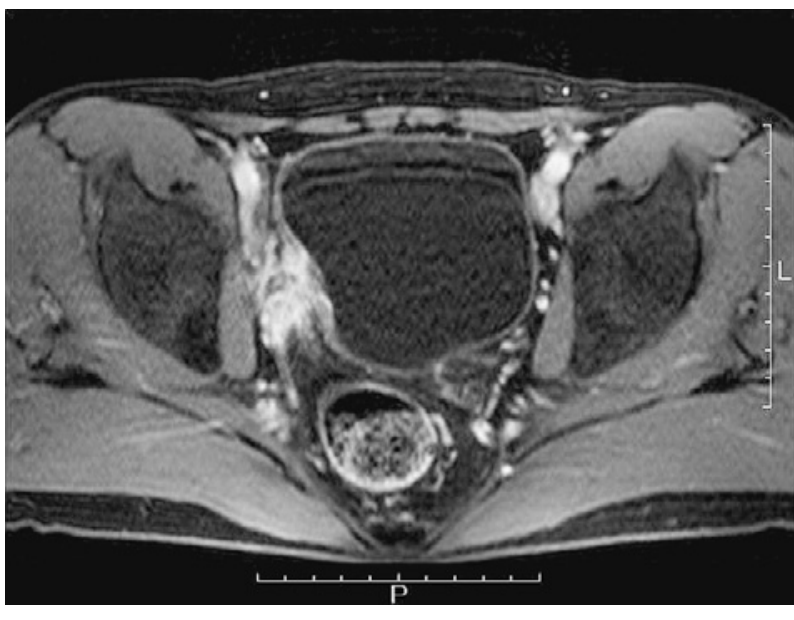

Fig. 3 手術標本肉眼的所見

TUR 部は陥凹していたが (矢印), 周囲の膀胱粘膜は正 常であった

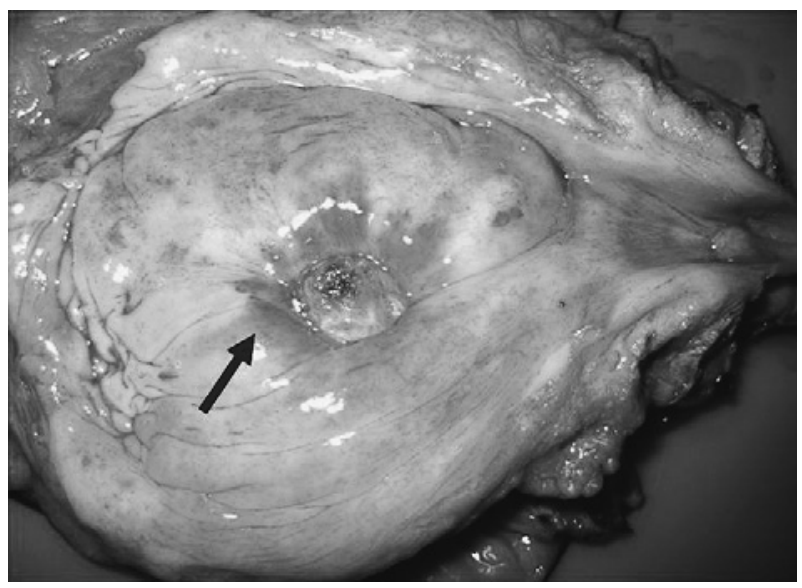

時点の MRI で腫瘍は約 $29 \mathrm{~mm}$ 大に縮小しており（Fig. $2)$, 同年 4 月に右腎尿管全摘出, 膀胱尿道全摘除および 回腸導管造設術を施行した. 手術時間は 11 時間 41 分,

出血量は $1,720 \mathrm{ml}$ であった

手術標本 : TUR 部は陥凹していたが, その周囲の膀胱 粘膜は正常であった (Fig. 3). 右腎尿管には肉眼的に腫瘍 は認めず，右尿管は腫瘍により圧迫されていた。

病理組織学的所見: 浸潤性の強いwell-moderately differentiated squamous cell carcinoma が膀胱固有筋層 から膀胱周囲を中心に広がっていた (Fig. 4A). 膀胱内腔

の腫瘤はほぼnecrosis を来たし, その近傍に 1 切片のみ 上皮内癌（CIS）をわずかに認めた（Fig. 4B）。病理組織 診 断はurothelial carcinoma with squamous cell differentiation であり，膀胱原発腫瘍と確定診断に至った。

術後経過: 術後補助化学療法として weekly TC 療法 を 2 コース施行後は再発を認めていなかったが, 術後 11 力月目に右腸腰筋に再発を疑う充実性腫瘤, 肝に転移を 疑う腫瘤を認め, weekly TC 療法開始. 2 コース施行後の 腹部 CT で右腸腰筋の局所再発部は増大傾向であったた め, GC 療法開始 (gemcitabine $1,000 \mathrm{mg} / \mathrm{m}^{2}$ on Day1, Day 
Fig. 4 手術標本病理組織学的所見

A : H.E. 染色 強い角化を認め, 腫瘍の大部分を占めていた

B : CIS は 1 切片のみ認められた（シェーマ）
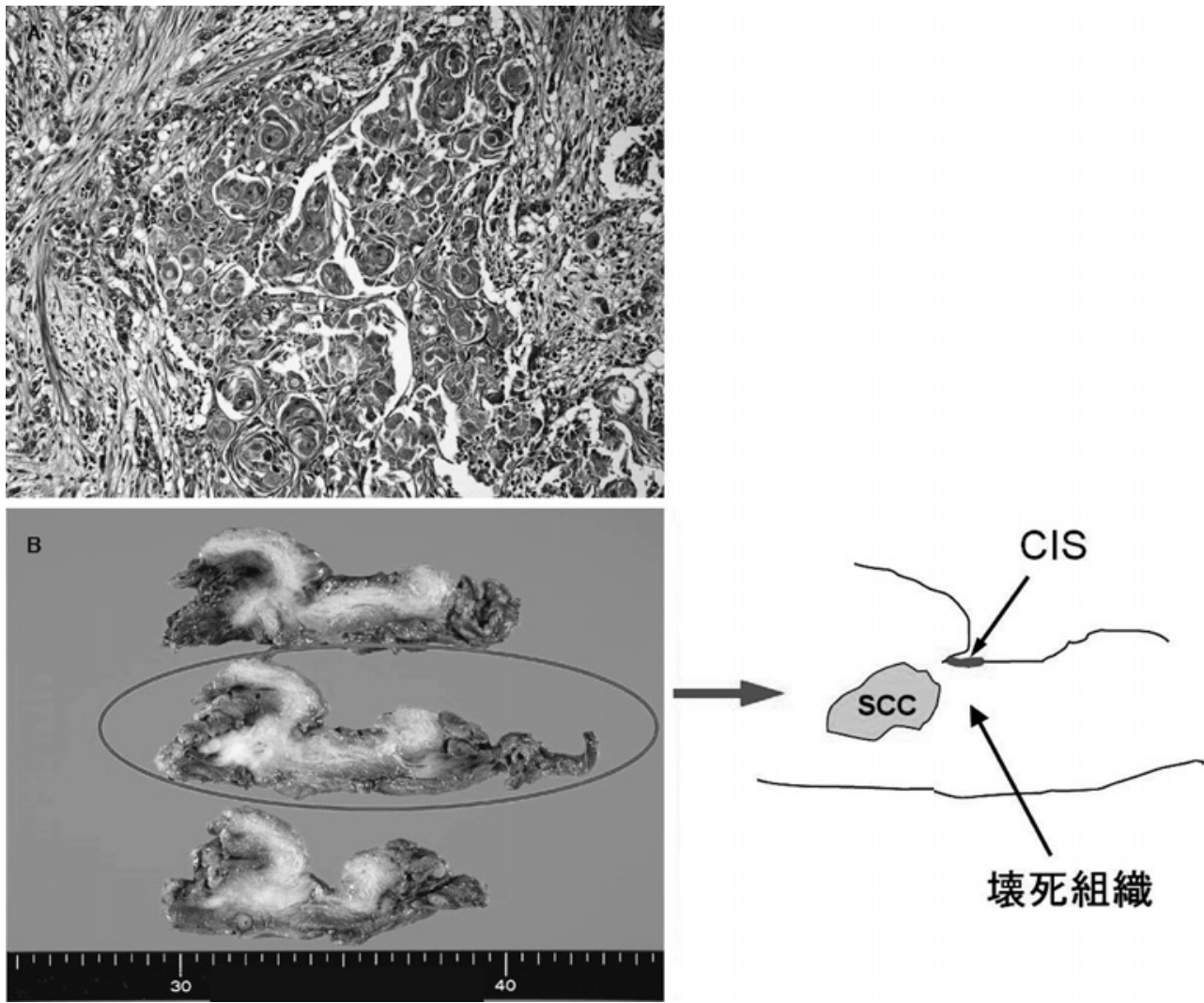

8, cisplatin $70 \mathrm{mg} / \mathrm{m}^{2}$ on Day2, 21 日 cycle). 血清 Cr 5.90 $\mathrm{mg} / \mathrm{dl}$ まで上昇し中止. 術後 16 力月目には肺転移出現. 右腸腰筋腫瘍が腸管に浸潤し消化管出血を来し, 術後 17 カ月で永眠された。

\section{考察}

膀胱癌取扱規約第 3 版 ${ }^{1}$ までは同一腫瘍の中に 2 種類 以上の組織型が混在する場合には, 量的に優勢なものを 主診断とし,他の組織型を付記するものと記されていた. 腎盘・尿管・膀胱癌取扱規約第 1 版 ${ }^{2}$ からは扁平上皮癌 の割合に関わらず，尿路上皮癌の成分が含まれていれば Urotelial carcinoma with squamous cell differentiation, 扁平上皮癌の組織型しか認めないものを Squamous cell carcinoma とすることに改訂された. 今回の症例はTUR 標本では扁平上皮癌の成分しか認めず, 全摘標本でも一 部にのみ CIS を認めており, 従来までは扁平上皮癌とし て治療をされていたケースと思われる. 膀胱扁平上皮癌 は本邦では全膀胱癌のうち約 $5 \%$ を占める，尿路上皮癌 に比し遠隔転移が少なく, 強い局所浸潤傾向を示し, 診 断時には進行癌となっていることが多く, 大半が診断後 $1 \sim 3$ 年以内に死亡している ${ }^{3)}$. 一般に外科的摘除が第一 選択であり, 有効な補助療法は確立されていない. 林ら ${ }^{4)}$ は浸潤性膀胱扁平上皮癌 18 例を検討し, StageIII 以上の 症例では補助療法を推奨し, 具体的には cisplatin を主体
として化学療法併用放射線療法が最も有効性が高いとし ている. Pure squamous cell carcinoma (SCC) と urothelial carcinoma with squamous cell differentiation (TCC/ SCC)に分けて治療成績を検討したものとして, Ehdaie ${ }^{5)}$ と Rausch ${ }^{6}$ の報告がある. Ehdaie らは SCC 78 例, TCC/ SCC 67 例を検討し，TCC/SCC は SCC に比べ男性に多 い傾向であり, SCC の 5 年生存率は $40 \%$, 癌特異的生存 率は $58 \%, \mathrm{TCC} / \mathrm{SCC}$ の 5 年全生存率は $31 \%$, 癌特異的 生存率は $39 \%$ であったと報告している。全体の $17 \%$ で 術前補助化学療法を施行しており，そのうち約半数の症 例で GC 療法を選択していた. Rausch らはSCC 31 例と TCC/SCC 11 例を検討しており，SCC と TCC/SCC の 5 年生存率はそれぞれ $27 \% ， 26 \%$ であったと報告してい る. Rausch らは術前補助療法を施行しておらず， 4 例 （9\%）で術後補助療法を施行していた（化学療法 2 例, 放射線療法 1 例, 化学放射線療法 1 例).

本症例は, 当初は後腹膜扁平上皮癌の診断であった. 診断時点での報告例は本邦・海外を含め 4 例のみで7 10) 全例腫瘍摘除術を施行していたが，そのうち 2 例が局所 再発で 1 年以内に死亡していた ${ }^{8) 9}$. 術前補助療法を施行 していた症例はなかったが，本症例では根治性を高める ことを目的に術前補助化学療法を施行する方針とした。 頭頚部癌, 食道癌, 肺癌の扁平上皮癌に準じた化学療法 を検討し，どのレジメンもプラチナベースの治療法で 
あった. 肺扁平上皮癌の $\mathrm{TC}$ 療法において, 奏功率, 無増 悪期間, 全生存率について carboplatin が cisplatin に比 し非劣性というエビデンスがある ${ }^{11}$. 今回我々は, 患者の 強い希望もあり, 外来治療可能な肺扁平上皮癌に準じた TC療法を選択した. 2 コース施行予定であったが，1 コース終了時点の画像評価で腫瘍は縮小し, 内閉鎖筋へ の浸潤も解除されており, 摘除可能と判断し, 手術に踏 み切った。

膀胱扁平上皮癌の補助療法については移行上皮からの 扁平上皮化性という変化を踏まえ, MVAC や GC など従 来の尿路上皮癌としての化学療法を選択するケースも多 い. 局所浸潤傾向が強いため十分な外科的マージンを確 保した切除が必要で, 今回の TC 療法は安全に施行でき, 良好な抗腫瘍効果が得られた。昨今, がんゲノムアトラ ス (TCGA) プロジェクトにおける筋層浸潤性膀胱癌の統 合解析において, 膀胱癌の治療候補となりうる遺伝子変 異や新たな遺伝子変異が報告された ${ }^{12)}$. その中で, 扁平上 皮癌の特徵を認めるものについて, cytokeratin や epidermal growth factor receptor(EGFR)が高発現であり, この発現形式が肺や頭頸部の扁平上皮癌と類似してお り, これらの癌が共通した経路をたどり腫瘍化する可能 性が示唆され, 今後膀胱扁平上皮癌についても肺癌や頭 頚部癌の治療法を応用できるかもしれない. 扁平上皮成 分を含む尿路上皮癌については, 本症例のような肺扁平 上皮癌に準じた TC 療法も選択肢の一つとなりうると思 われる。

\section{文献}

1) 日本泌尿器科学会日本病理学会編 : 泌尿器科 - 病理 膀胱癌取扱規約, 第 3 版, p 50-55, 金原出版, 東京, 2008.

2) 日本泌尿器科学会 - 日本病理学会 - 日本医学放射線 学会編 : 泌尿器科・病理・放射線科 腎盂・尿管・ 膀胱癌取扱規約, 第 1 版, p 87-100, 金原出版, 東京, 2011.

3) Abol-Enein H, Kava BR and Carmack AJ: Nonurothelial Cancer of the Bladder. Urology, 69, 93104, 2007.

4）林 典宏, 浅野晃司, 古田 昭, 池本 庸, 岸本幸一, 山崎春城, 大西哲郎, 高橋浩幸, 大石幸彦 : 浸潤性膀
胱扁平上皮癌 18 例の臨床的検討. 日泌尿会誌，95, 711-717, 2004.

5) Ehdaie B, Maschino A, Shariat SF, Rioja J, Hamilton RJ, Lowrance WT, Poon SA, Al-Ahmadie HA and Herr HW: Comparative outcomes of pure squamous cell carcicoma and urothelial carcinoma with squamous cell differentiation in patients treated with radical cysterectomy. J Urol., 187, 74-79, 2012.

6) Rausch S, Hofmann R and von Knoblotch R: Nonbilharzial squamous cell carcinoma and transitional cell carcinoma with squamous cell differentiation of the lower and upper urinary tract. Urol Ann., 4, 14-18, 2012.

7）伊神 剛, 長谷川洋, 小木曽清二, 塩見正哉, 籾山正 人, 大平周作, 高橋 祐, 雨宮 剛, 上原圭介, 宮崎 晋, 都築豊徳 : 後腹膜に巨大な腫瘤を形成した低分 化扁平上皮癌の一例．癌の臨，46, 389-393, 2000.

8) Khalil AM, Shabb NS, Hourani MH, Shamseddine AI, El-haji MI and Seoud AF: Primary squamous cell carcinoma of the pelvic retroperitoneum presenting as an adnexal mass: a case report. J Obstet Gynecol., 25, 92-93, 2005.

9）杉本貴昭, 黒田暢一, 城 大介, 岡本共弘, 藤本治朗 : 後腹膜巨大腫瘤型低分化扁平上皮癌の一例. 日外科 系連会誌, 24, 961一968, 2009.

10) Chen $\mathrm{CH}$, Yeh SD, Chiou JF, Lin YH and Chang CW: Optimum treatment for primary squamous cell carcinoma of the pelvic retroperitoneum. J Exp Clin Med., 6, 304-306, 2011.

11) Scagliotti GV, De Marinis F, Rinaldi M, Crinò L, Gridelli C, Ricci S, Matano E, Boni C, Marangolo M, Failla G, Altavilla G, Adamo V, Ceribelli A, Clerici M, Di Costanzo F, Frontini L and Tonato M: Italian Lung Cancer Project: Phase III randomized trial comparing three platinum-based doublets in advanced non-small cell lung cancer. J Clin Oncol., 20, 4285-4291, 2002.

12) Cancer Genome Atlas Research Network: Comprehensive molucular characterization of urothelial bladder carcinoma. Nature, 507, 315-322, 2014. 


\title{
A CASE OF UROTHELIAL CARCINOMA OF THE URINARY BLADDER WITH SQUAMOUS DIFFERENTIATION RESPONDING TO PACLITAXEL AND CARBOPLATIN NEOADJUVANT CHEMOTHERAPY
}

\author{
Eri Banno", Aki Nishino", Yasuharu Nagai ${ }^{1)}$, Muneo Yasuda ${ }^{1)}$, Hideo Tahara ${ }^{1)}$, Shigeo Kino ${ }^{2)}$ and Norihumi Kanno ${ }^{3)}$ \\ ${ }^{1)}$ Department of Urology, Mimihara General Hosipital \\ ${ }^{2)}$ Department of Pathology, Mimihara General Hospital \\ ${ }^{3)}$ Kanno Clinic
}

\begin{abstract}
:
A 42-year-old man was referred to our hospital for macrohematuria. Computer tomography and magnetic resonance imaging revealed right hydronephrosis and a retroperitoneal mass, located next to right side of the bladder. Cystoscopy showed a protruded lesion covered with normal mucosa at the right lateral wall. The patient underwent transurethral resection of the bladder tumor and biopsies of the bladder wall. Histological examination showed squamous cell carcinoma. Neoadjuvant chemotherapy using paclitaxel and carboplatin (TC) was performed. A total cystectomy, right nephroureterectomy and construction of the ileal conduit were performed after one course of systemic chemotherapy. Histological examination showed urothelial carcinoma with squamous cell differentiation. Unexpectedly, a small amount of CIS was detected only in the vicinity of the TUR scar. The patient received 2 cycles of TC chemotherapy as adjuvant chemotherapy. Unfortunately, 11 months later, local recurrence and liver metastasis were detected. He died 17 months after the surgery.
\end{abstract}

(Jpn. J. Urol 106(3): 206-210, 2015)

Keywords: paclitaxel, squamous cell carcinoma, neoadjuvant chemotherapy

Received: September 19, 2014, Accepted: December 3, 2014

(C) 2015 The Japanese Urological Association 